\title{
ॠUSGS
}

science for a changing world

In Cooperation with the World Bank, the Mauritania Ministry of Mines Industry, and Futures Group

\section{Environmental Stratification Framework and Water- Quality Monitoring Design Strategy for the Islamic Republic of Mauritania, Africa}

By Michael J. Friedel

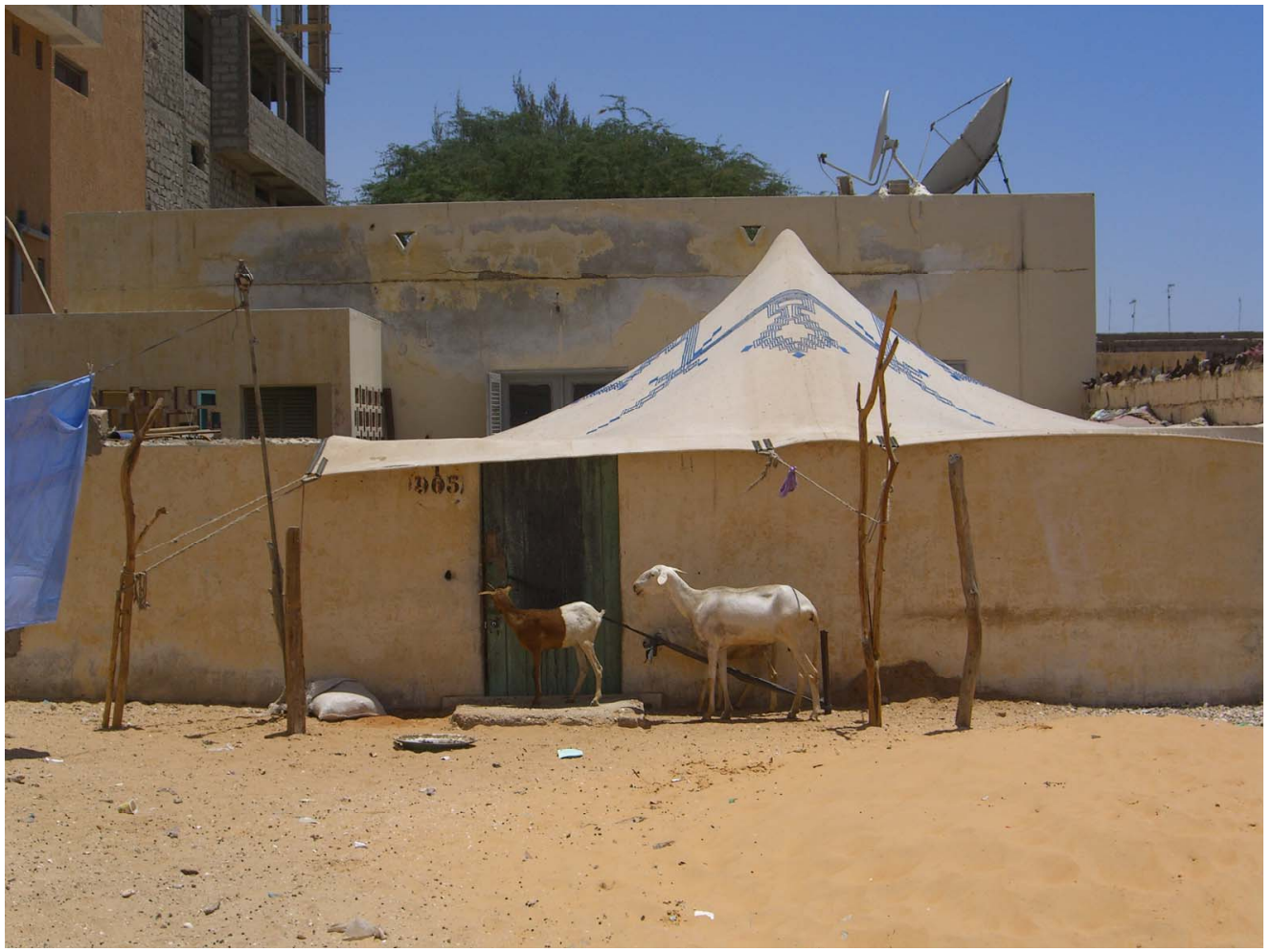

Open-File Report 2008-1137

U.S. Department of the Interior

U.S. Geological Survey 


\section{U.S. Department of the Interior DIRK KEMPTHORNE, Secretary}

\section{U.S. Geological Survey \\ Mark D. Myers, Director}

U.S. Geological Survey, Reston, Virginia 2008

For product and ordering information:

World Wide Web: http://www.usgs.gov/pubprod

Telephone: 1-888-ASK-USGS

For more information on the USGS - the Federal source for science about the Earth, its natural and living resources, natural hazards, and the environment:

World Wide Web: http://www.usgs.gov

Telephone: 1-888-ASK-USGS

Suggested citation:

Friedel, M.J., 2008, Environmental stratification framework and water-quality monitoring design strategy for the Islamic Republic of Mauritania, Africa: U.S. Geological Survey, Open-File Report 2008-1137. 17 p.

Any use of trade, product, or firm names is for descriptive purposes only and does not imply endorsement by the U.S. Government. 


\section{Contents}

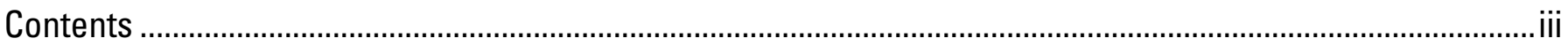

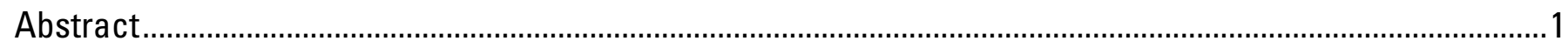

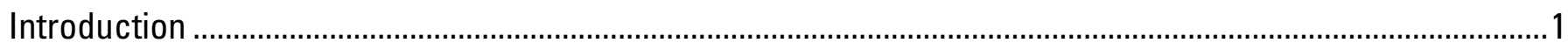

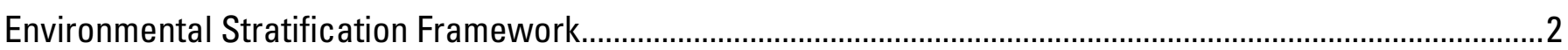

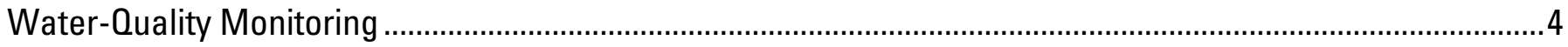

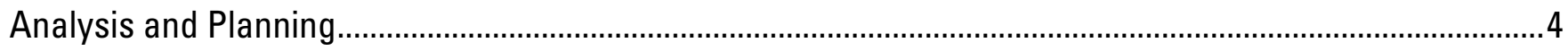

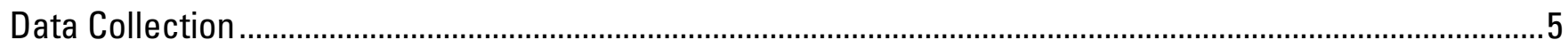

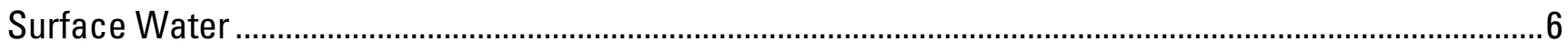

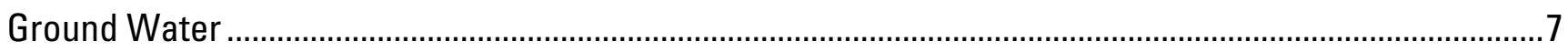

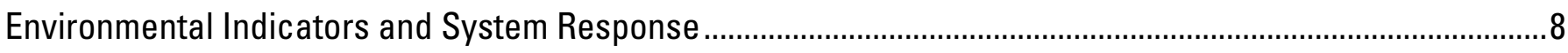

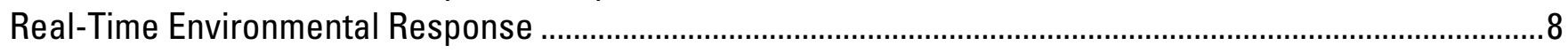

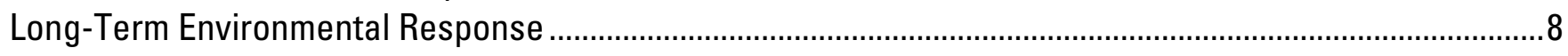

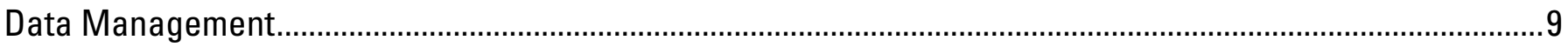

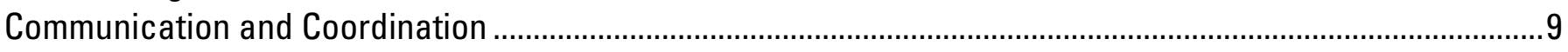

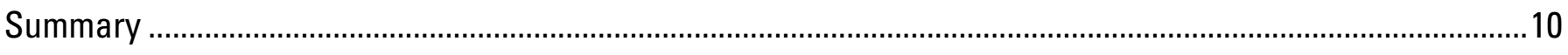

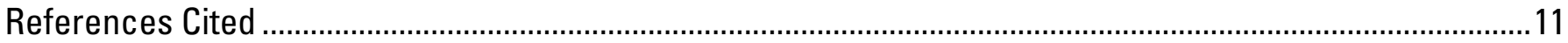




\section{Figures}

Figure 1. Fundamental hydrologic landscape unit characterized by surface runoff, ground-water flow, and interaction with atmospheric water (after Winter, 2001).

Figure 2. Basin priority mine settings produced by combining hydrologic landscapes with deposit

groups. 13

Figure 3. Nested scales of investigation. ...............................................................................................14

Figure 4. Environmental framework used to synthesize water quality assessment findings............................15

Figure 5. Study Unit (gray outline) priority mine setting derived by combining deposit groups (source) with hydrologic landscapes (transport). The Study Unit is an integrator basin comprised of smaller homogeneous polygons (red, blue, green). Circles indicate possible monitoring locations; e.g., surface water hydrology and/or ecology at outlets of tributary basins; ground water within individual colored polygons.

\section{Table}

Table 1. Summary of water-quality assessment activities 


\title{
Environmental Stratification Framework and Water- Quality Monitoring Design Strategy for the Islamic Republic of Mauritania, Africa
}

\author{
By Michael J. Friedel
}

\begin{abstract}
Mauritania anticipates an increase in mining activities throughout the country and into the foreseeable future. Because mining-induced changes in the landscape are likely to affect their limited ground-water resources and sensitive aquatic ecosystems, a water-quality assessment program was designed for Mauritania that is based on a nationally consistent environmental stratification framework. The primary objectives of this program are to ensure that the environmental monitoring systems can quantify near real-time changes in surface-water chemistry at a local scale, and quantify intermediate- to long-term changes in groundwater and aquatic ecosystems over multiple scales.
\end{abstract}

\section{Introduction}

Mauritania anticipates an increase in mining activities throughout the country, and into the foreseeable future. Because mining-induced changes in the landscape are likely to affect their limited ground-water water-resources and sensitive aquatic ecosystems, the United States Geological Survey (USGS), in cooperation with the Government of Mauritania, designed a waterquality assessment program for Mauritania that is based on a nationally consistent environmental stratification framework. The suggested program draws on experience gained from the USGS National Water Quality Assessment (NAWQA) program (Gilliom and others, 1995; Friedel, 1998), 
and the recently designed Romanian environmental monitoring assessment program (Wnuk and others, 2007).

The primary objectives of the Mauritanian water-quality assessment program are to ensure that the environmental monitoring systems can quantify near real-time (short-term) changes in surface-water chemistry at a local-scale, and quantify intermediate- to long-term changes in groundwater and aquatic ecosystems over multiple scales. Implementation and analysis of these nested environmental response systems will allow Mauritanian scientists and managers to describe current resource-quality conditions (freshwater streams and aquifers), describe temporal water quality conditions, and improve understanding of the primary factors affecting the water-resource quality. Repeated application of these assessments will show whether certain types of water-quality issues are isolated or pervasive, and will allow direct comparisons of how human activities and natural processes affect water quality and ecological health in diverse geographic and environmental settings. Synthesis of this information across a nationally consistent environmental framework is needed so that Mauritanian resource managers can implement effective management actions and evaluate short- and long-term changes in water quality.

\section{Environmental Stratification Framework}

An environmental stratification framework is suggested for monitoring network design and synthesis of water-quality assessment findings. The elements of the environmental stratification framework are based on the general risk model involving source, transport, and receptor. In Mauritania, some potential sources that may contribute to water-quality changes include existing and changing landscapes, such as mineral deposits, and agriculture, mining, and urban activities. These natural and anthropogenic sources introduce complex physical, chemical, and biological stresses across the hydrogeologic landscape. In turn, these stressors may affect the quality of waterresources resulting in various hazards. Examples of mining-related hazards include deteriorating infrastructure, engineering and environmental failures, and mining influenced waters. Some environmental failures include dust, erosion, earthquakes, reactive transport, preferential flow, radiation, runoff, and seepage. In cases where water comes in contact with mine waste rock or processed tailings, these waters may generate sulphuric acid and release metals in the presence of sulphide minerals. Likewise, water percolating through waste rock or tailings containing uranium minerals can release thorium-230, radium-226, radon gas, and metals. 
Depending on the scale of the analysis, water-quality hazards may present risks to aquatic or human health (receptors). The magnitude of these potential risks is associated with factors controlling transport along landscape pathways between a hazard and receptor - called a hydrologic landscape (Winter, 2001). A fundamental hydrologic landscape unit is defined by the land-surface form, geology, and climate. The basic hydrologic landscape land-surface form is an upland separated from a lowland by an intervening steeper slope (fig. 1). Fundamental hydrologic landscape units are characterized by a hydrologic system consisting of surface runoff, ground-water flow, and interaction with atmospheric water. By describing actual landscapes in terms of landsurface slope, hydraulic properties of soils and geologic framework, and the difference between precipitation and evapotranspiration, the hydrologic system of actual landscapes can be conceptualized in a uniform way across Mauritania.

The purpose of defining hydrologic landscape regions is to group Mauritanian basins according to their similarity in landscape characteristics (aquifer characteristics, soil types, and topography) and climate characteristics (difference between precipitation and evapotranspiration). These selected characteristics represent factors assumed to affect hydrologic processes in the environment. The process used to define hydrologic landscapes in Mauritania should involve three steps: aggregating national geographic information systems data defined at prescribed resolution (such as $250 \mathrm{~m}$ x $250 \mathrm{~m}$ pixels); performing principal component analysis of the land-surface form, geologic texture, and climate characteristics to remove co-dependence among the variables; and assigning study basins to a group on the basis of low within-cluster variance and separation among the clusters. One suggested hierarchical method is to use a minimum variance criterion and nearest neighbor chain algorithm (Murtagh, 1985). Once the variations of fundamental hydrologic landscape units are generated, they can be combined with individual or group of source landscape (or land-use) features to establish a suitable national monitoring network.

At the local scale, identification of priority groundwater or surface water monitoring networks needs to coincide with superposition of basins that define the fundamental study scale of most interest to the Mauritanian government. In the NAWQA program, factors such as population, magnitude of domestic water-resource use were used to prioritize study size and location of basins, called Study Units. Priority factors may differ in Mauritania and therefore require their identification by local scientists. The Mauritanian Study Units should represent major hydrologic systems where water-quality studies will be focused. For example, Study Units might be geographically defined by a combination of ground- and surface-water features of more than 
10,000 square kilometers of land. The suggested total number of Study Units in the water-quality assessment should range between 30 to 60 for analysis and synthesis at regional and national scales. This conceptual framework provides the foundation for design studies, monitoring networks, and syntheses and comparison of processes of information.

Superposition of Mauritanian Study Units together with the priority hydrologic landscapes will provide a grid that can be used in the statistical design of sampling networks. In the example provided (fig. 2), a source setting, such as deposit groups, is combined with hydrologic landscape regions to yield a map of priority environmental basins. The same type of hydrologic landscape region can occur in different parts of the country indicating that the hydrologic-landscape characteristics of basins in these geographically disparate sections are similar. The environmental framework balances the potentially unique assessment requirements for an individual Study Unit with a nationally consistent design and data-collection structure that incorporates a multi-scale, interdisciplinary approach.

\section{Water-Quality Monitoring}

The suggested water-quality monitoring activities are designed to begin at different times and occur over a different number of years (table 1). Groups of 10-15 Study Units are anticipated to overlap (one cycle) to ease the potential financial burden of implementing a national water-quality assessment program. In the first year, available water-quality data should be analyzed and used to establish final Study Unit monitoring designs. After the analysis and planning period, surfacewater, ground-water, and biological data should be collected intensively for 3 years (termed the high-intensity phase). A low-intensity phase follows the high-intensity phase for 6 years, during which water quality is monitored at fewer sites and areas than were assessed earlier. This combination of high- and low-intensity monitoring phases will allow Mauritanian scientists time to examine trends in water quality and biota to develop meaningful environmental indicators.

\section{Analysis and Planning}

During the analysis and planning period, available data and results from each Study Unit should be reviewed to understand the primary physical, chemical, and biological factors that affect water quality and to identify data gaps. Descriptions of how natural (soils, geology, physiography, climate, drainage) and anthropogenic (agricultural and mining activities, and urbanization) landscape characteristics may affect water-quality should be compiled and made available. 
Information obtained from reviews of previous monitoring studies, field checks of existing monitoring stations and candidate sampling sites, and field reconnaissance data should be in the final design of the sampling program for each Study Unit.

During the high-intensity phase, chemical, physical, biological, and habitat data should be collected at varying scales to describe the water quality throughout each Study Unit. Measurements should be made to determine streams, aquifers, and sediment chemistry; the variety and number of fish, benthic invertebrates, and algae in streams; and the presence of any contaminants in fish tissues. Specific streams and aquifers, chemical constituents, and biological species need to be selected for sampling that represent the important water resources and water-quality concerns in each Study Unit and the nation. Collecting multiple aquatic organisms is important because of their different capacities to integrate changing water-resource stresses; for example, algae, benthic invertebrates, and fish tend to respond to water-quality changes over weeks, months, and years, respectively.

\section{Data Collection}

Individual Study Unit assessments should be designed for future repeated application, so the status of, and trends in, the quality of the Mauritania's ground- and surface-water resources can be assessed and link the status and trends with an understanding of natural (climate change) and anthropogenic (mining and agriculture) factors that may affect water quality. This study design balances the potentially unique assessment requirements for an individual Study Unit with a nationally consistent design and data-collection structure (fig. 3). For example, existing and new surface- and ground-water studies conducted at local, regional, and national scales can be examined to understand the water-quality conditions and their persistence that may arise due to mining activities. An occurrence and distribution (baseline) assessment is the largest and most important component of the first intensive study phase in each Study Unit. The goal of this baseline assessment is to characterize the broad-scale geographic and seasonal distributions of water-quality conditions across the nation (fig. 4). For this reason, the analytical services for chemical and ecological constituents should be conducted at a recognized laboratory to ensure consistency of results with international standards. The following discussions describe the typical surface- and ground-water monitoring components of the occurrence and distribution assessment. 


\section{Surface Water}

The suggested Study Unit design for surface water shall focus on water-quality conditions in streams using three interrelated components: water-column studies, bed-sediment, and ecological studies. Water-column studies shall monitor physical characteristics (dissolved oxygen, $\mathrm{pH}$, specific conductance, temperature, and turbidity) and chemical characteristics, which include carbon (inorganic, organic, total), isotopes $\left(\mathrm{O}^{18}\right.$, Deuterium), major ions $\left(\mathrm{Ca}, \mathrm{Cl}, \mathrm{Fe}, \mathrm{HCO}_{3}, \mathrm{Mn}\right.$, $\left.\mathrm{Mg}, \mathrm{Na}, \mathrm{Si}, \mathrm{S}, \mathrm{SO}_{4}\right)$, nutrients $\left(\mathrm{N}, \mathrm{NH}_{4}, \mathrm{NO}_{3}, \mathrm{P}, \mathrm{PO}_{4}\right.$ ), redox couple (iron or arsenic), suspended sediment, trace metals ( $\mathrm{As}, \mathrm{Al}, \mathrm{Au}, \mathrm{Cd}, \mathrm{Cu}, \mathrm{Hg}, \mathrm{Pb}, \mathrm{Se}, \mathrm{Th}, \mathrm{Zn}$ ), and their relation to hydrologic conditions (streamflow discharge), sources, and transport. Surface water shall be monitored at sites termed either basic-fixed sites or intensive-fixed sites according to the frequency of depth- and width-integrated sampling techniques (Edwards and Glysson, 1988).

The depth- and width-integrated sampling sites in the study basin should be selected to determine the water quality in relation to priority environmental settings (agriculture, dunes, mining, urban, and possibly others). Each Study Unit basin should have 8-10 basic-fixed and 2-3 intensive-fixed sites. Basic-fixed sites shall be sampled monthly and at high stream flows for 2 years of the 3-year high-intensity phase. The intensive-fixed sites shall be monitored more frequently (as often as weekly during key times such as high flow events) for at least 1 year to characterize short-term variations of water quality. Basic-fixed or intensive-fixed sites can be either indicator or integrator sites. Indicator sites shall represent small (less than about 200 square kilometers) and relatively homogeneous polygons associated with specific environmental settings, such as a mining land use that substantially affects water quality in the Study Unit (fig. 5). Integrator sites should be established at downstream points (preferably at a Study Unit basin outlet) in a large (thousands of square kilometers) and relatively heterogeneous (multiple polygons) drainage basin with complex combinations of environmental settings. Nesting of these sites shall be done by ensuring that indicator sites are located in the drainage basins of an integrator site.

In addition to depth- and width-integrated sampling in the water column, two continuously recording (15-minute to 60-minute intervals) water-quality probes with real-time satellite transmission need to be installed and co-located with streamflow-gaging stations for monitoring specific conductance, $\mathrm{pH}$, water temperature, turbidity, and dissolved oxygen. One real-time waterquality probe should be in an indicator tributary basin characterized by mining activities, whereas the second probe could be placed at the confluence of the rivers that represent the integration of environmental settings; for example, the outlet of a Study Unit. 
Ecological studies will reveal relations among physical, chemical, and biological characteristics of streams. Aquatic biological communities at the basic- and intensive-fixed sites should be surveyed during the 3 years of the high-intensity-sampling phase. These surveys will be done along a delineated stream reach and include a habitat assessment of the site and annual surveys of the algae, benthic invertebrate, and fish communities. Assessing the occurrence and distribution of these biological communities will be important because they each have varying time-dependent integrating water-quality capacities. Ecological sampling should be integrated with surface-water synoptic (short-term) sampling during low flow to provide greater spatial coverage and to assess whether the biological communities at basic- and intensive-fixed sites represent streams throughout the study basin. During the low-flow synoptic, samples from bed-sediment, fish communities, fish tissues, and water should be collected at about 30-50 tributary basin sites that are affected by mining activities to assess the occurrence and distribution of trace metals.

\section{Ground Water}

The Study Unit design for ground water should focus on water-quality conditions in aquifers with emphasis on recently recharged ground water that may be associated with current or recent human activities, by using subunit surveys and land-use studies. Subunit surveys will be designed to assess the water quality of major aquifers or systems of aquifers in each study basin. About 30 wells should be randomly selected for sampling during one subunit survey. Land-use studies are designed to focus on recently recharged and shallow aquifer systems so that the effects of mining practices and natural conditions can be assessed. About 20-30 new monitoring wells should be randomly located and installed within each land-use type. Suggested ground-water analyses include physical (dissolved oxygen, $\mathrm{pH}$, specific conductance, and temperature, turbidity) and chemical characteristics, which include carbon (inorganic, organic, total), Chloroflurocarbons, dissolved gases ( $\left.\mathrm{Ar}, \mathrm{Ar}+\mathrm{O} 2, \mathrm{CH}_{4}, \mathrm{CO} 2, \mathrm{~N} 2, \mathrm{O} 2\right)$, isotopes $\left(\mathrm{O}^{18}\right.$, Deuterium), major ions $(\mathrm{Ca}, \mathrm{Cl}, \mathrm{Fe}$, $\mathrm{HCO}_{3}, \mathrm{Mn}, \mathrm{Mg}, \mathrm{Na}, \mathrm{Si}, \mathrm{SO}_{4}$ ), nutrients $\left(\mathrm{N}, \mathrm{NH}_{4}, \mathrm{NO}_{3}, \mathrm{P}, \mathrm{PO}_{4}\right.$ ), redox couple (iron or arsenic), trace metals ( $\mathrm{As}, \mathrm{Al}, \mathrm{Au}, \mathrm{Cd}, \mathrm{Cu}, \mathrm{Hg}, \mathrm{Pb}, \mathrm{Se}, \mathrm{Th}, \mathrm{Zn}$ ), and Tritium. Findings in terms of analyses from the land-use studies can be compared to those findings from the subunit survey to determine the effect of mining on ground-water quality. 


\section{Environmental Indicators and System Response}

\section{Real-Time Environmental Response}

Water-quality indicators, such as conductance, oxygen, $\mathrm{pH}$, temperature, and turbidity, can be measured directly using a real-time water-quality probe, however, the concentrations of most dissolved constituents will need to be estimated based on relationships between these indicators and water-quality measurements collected at varying hydrologic conditions. Specifically, regression equations will be developed that express an empirical relation (linear or nonlinear) between dissolved chemical constituents and real-time water-quality indicators. These regression equations should be based on these data compiled during the analysis and planning (retrospective) period. To reduce uncertainty, these regression equations need to be reevaluated using data collected during high-intensive period to reduce uncertainty. If appropriate retrospective data are not available, then only data from the high-intensive period should be used. Similarly, regression relations will be developed between the water-quality indicators and streamflow discharge. Appropriate computer software needs to be written for the implementation for real-time web-based monitoring and prediction of priority chemical constituents at selected locations. Because these ambient, seasonal relations will be known, any anomalous predictions above a predetermined threshold can provide officials with a warning of a potential problem, such as the failure of a mine tailings dam. The uncertainty in indicator predictions will be determined by adding back randomly sampled residuals. In this way, confidence intervals can be assigned to the indicator predictions.

\section{Long-Term Environmental Response}

The intermediate- to long-term response indicators that could be developed are for surfacewater and ground-water environments. Development of surface-water environmental response indicators can be based on relations that exist between various ecologically derived metrics (for example, species richness, and indices of biotic integrity for fish, macroinvertebrates, and algae) and other factors (for example, percent mining activity, and various chemical concentrations in water and sediment). Whereas the ecological metrics can be used to evaluate the health of individual tributary basins, collectively this information could provide an overview of the Study Unit basin health. Because these relations would indicate the effect of mining activities on ecosystem health, this information would be useful for water-resource planning purposes. 
Development of baseline ground-water environmental response indicators could be based nominally on maps and time-series graphs of priority chemical constituents dissolved in groundwater that were collected during the high-intensive phase. Spatial estimation techniques can be used to explore spatial statistical relations to map water indicators. Boxplots and summary statistics of individual chemical constituents for all sample sites can provide a means for evaluating the Study Unit basin against future sampling following the implementation of management strategies and against other future Mauritanian river basin studies.

In addition to these more traditional approaches to identifying response indicators, multivariate analysis is suggested to evaluate if a single parameter can serve as a proxy for an assemblage of chemical constituents. The approach might involve three interrelated elements: (1) quantitative summarization and description of major patterns in community structure (fish, or invertebrate, or algae), (2) reduction of the number of environmental variables by summarizing parts of water-quality, streambed-sediment, habitat, and atmospheric data, and (3) identification and description of relations between patterns in community structure and patterns in water quality, streambed-sediment quality, habitat and atmospheric data. Examples of multivariate techniques that could be evaluated include principal components analysis and nonparametric multi-dimensional scaling (Ruhl, 1995). Principal components analysis is a projection of multiparametric data into 2or 3-dimensional space (a direct combination of original data), whereas nonmetric multidimensional scaling is a picture of relative rank distances (where the closer two points have higher correlation).

\section{Data Management}

Data management activities would focus on tracking, quality assurance, quality control, consistent handling, long-term storage of project data, and preparation of data tables for publication. A national data base management plan needs to be developed and provided to Study Unit personnel.

\section{Communication and Coordination}

Communication and coordination between the principal research consortium and other scientific and land- and water-management organizations is a critical component of all Study Units. The establishment of a liaison committee is suggested that consists of representatives of 
stakeholders and user groups, the private sector, Federal and other agencies, colleges and universities, professional societies, and industrial associations. Committee activities should include the exchange of information about local and basin-wide water-quality issues, identification of sources of data, assistance in the design and scope of study products, and the review of study planning documents and reports.

\section{Summary}

Mauritania anticipates an increase in mining activities throughout the country and into the foreseeable future. Because mining-induced changes in the landscape are likely to affect their limited ground-water resources and sensitive aquatic ecosystems, a water-quality assessment program is designed for Mauritania. Underlying the design is an environmental stratification framework for the monitoring network and synthesis of water-quality assessment findings. The elements of this framework are based on the risk model involving source, transport, and receptor. Monitoring activities of water-quality and ecological constituents are suggested to begin at different times and occur over a different number of years. Groups of 10-15 Study Units are anticipated to overlap (one cycle) to ease the potential financial burden of implementing a national program. During the analysis and planning phase, available data and results from previous studies will be reviewed to understand the primary physical, chemical, and biological factors affecting water quality and to identify data gaps. Individual Study Unit assessments are designed for future repeated application so the status of and trends in the quality of the Mauritania's ground- and surface-water resources can be assessed. The suggested Study Unit design for surface water shall focus on water-column studies, bed-sediment, and ecological studies, whereas the design for ground water will focus on water-quality conditions in aquifers with emphasis on recently recharged ground water that may be associated with current or recent human activities by using subunit surveys and land-use studies. Real-time water-quality indicators will be developed using regression equations that express an empirical relation between dissolved chemical constituents and real-time water-quality indicators. The intermediate- to long-term response indicators could be developed for surface-water, environmental response indicators based on relations between ecologically derived metrics and other explanatory factors. Finally, data management activities, as well as communication and coordination between the principal research consortium and other scientific and land- and water-management organizations, is suggested. 


\section{References Cited}

Edwards, T.K., and Glysson, G.D., 1988, Field methods for measurement of fluvial sediment: U.S. Geological Survey Open-File Report 86-531, 118 p.

Friedel, M. J., 1998, Upper Illinois River Basin, National Water Quality Assessment study unit: U.S. Geological Survey Fact Sheet, FS-072-98, 4 p.

Gilliom, R.G., Alley, W.M., and Gurtz, M.E., 1995, Design of the National Water-Quality Assessment Program--occurrence and distribution of water-quality conditions: U.S. Geological Survey Circular 1112, 33 p.

Murtagh, F., 1985, Multidimensional Clustering Algorithms: Vienna, Physica-Verlag, 189 p.

Ruhl, P.M., 1995, Surface-water-quality assessment of the upper Illinois River Basin in Illinois, Indiana, and Wisconsin: Analysis of relations between fish-community structure and environmental conditions in the Fox, Des Plaines, and Du Page River Basins in Illinois 1982-84: U.S. Geological Survey Water-Resources Investigations Report 94-4094, 50 p.

Wagner, R.J., Mattraw, H.C., Ritz, G.F., and Smith, B.A., 2000, Guidelines and standard procedures for continuous water-quality monitors site selection, field operation, calibration, record computation, and reporting: U.S. Geological Survey Water-Resources Investigations Report 00-4252, 53 p.

Winter, T.C., 2001, The concept of hydrologic landscapes: Journal of the American Water Resources Association, v. 37, no. 2, p. 335-350.

Wnuk, C., Friedel, M., Olson, R., Luppnow, D, 2007, Hazards risk mitigation and emergency preparedness project: technical assistance for mining waste facilities, final report submitted to World Bank, 753 p. 


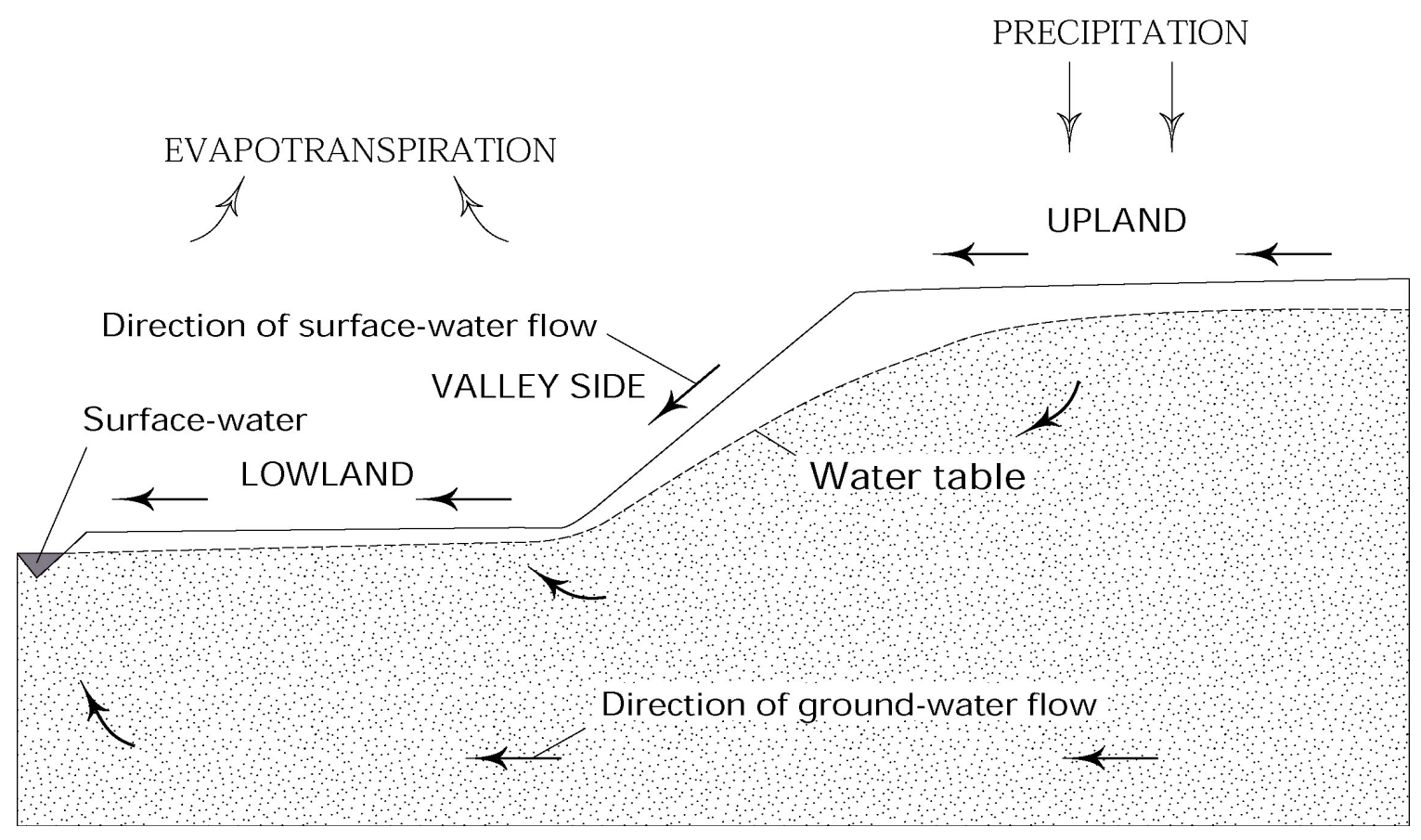

Figure 1. Fundamental hydrologic landscape unit characterized by surface runoff, ground-water flow, and interaction with atmospheric water (after Winter, 2001). 


\section{Scale: $250 \mathrm{~m}^{2}$ pixel}

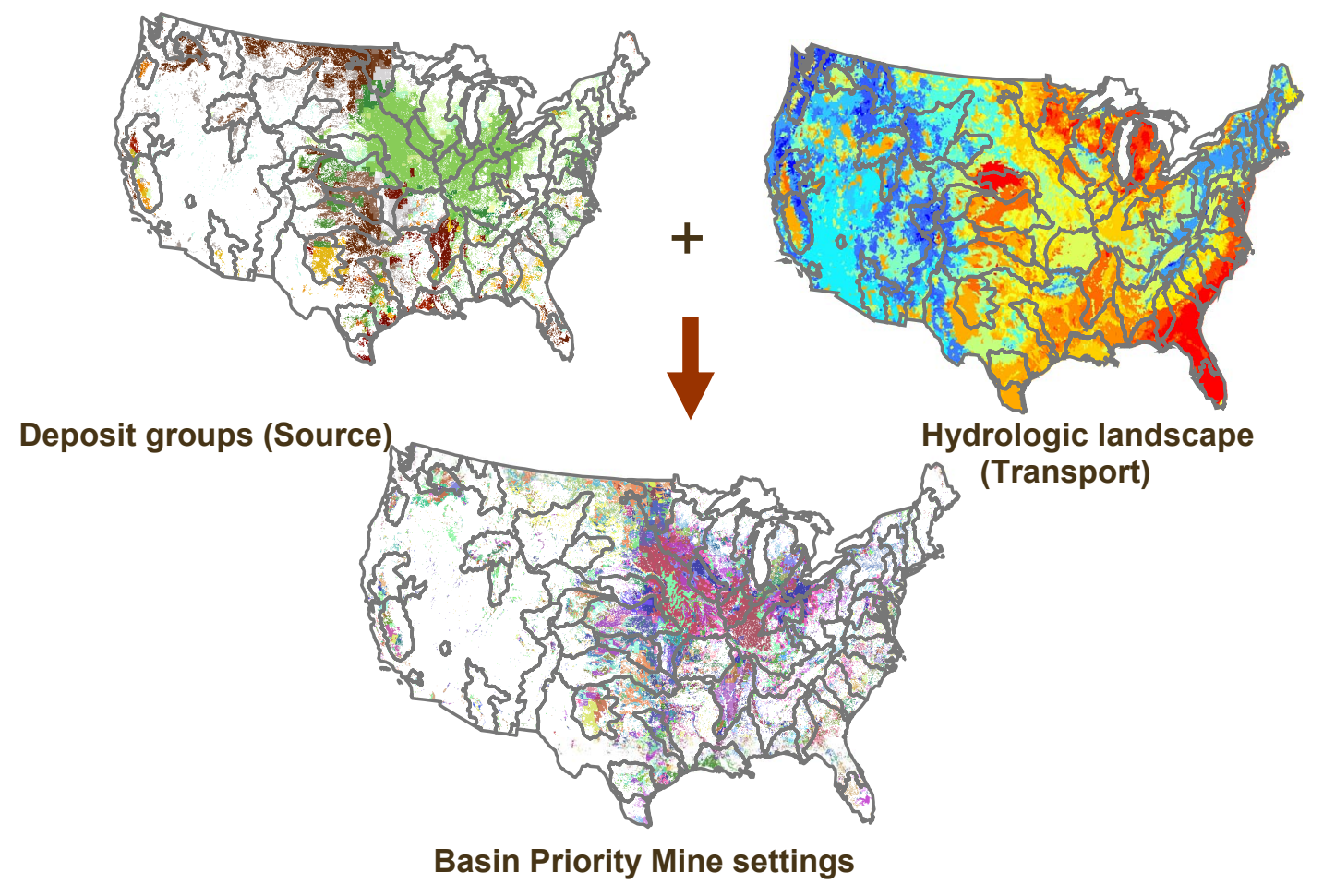

Figure 2. Basin priority mine settings produced by combining hydrologic landscapes with deposit groups. 


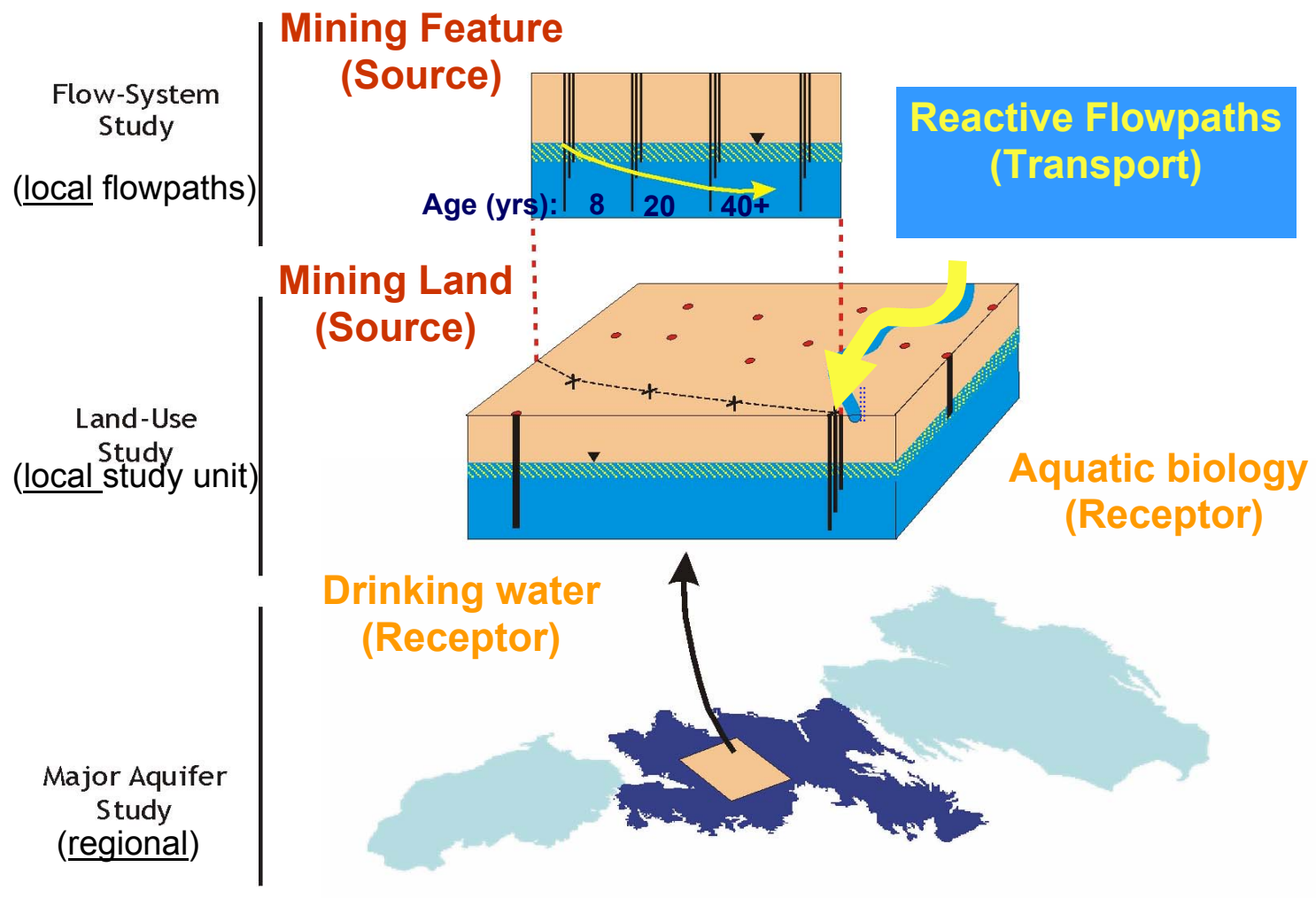

Figure 3. Nested scales of investigation. 


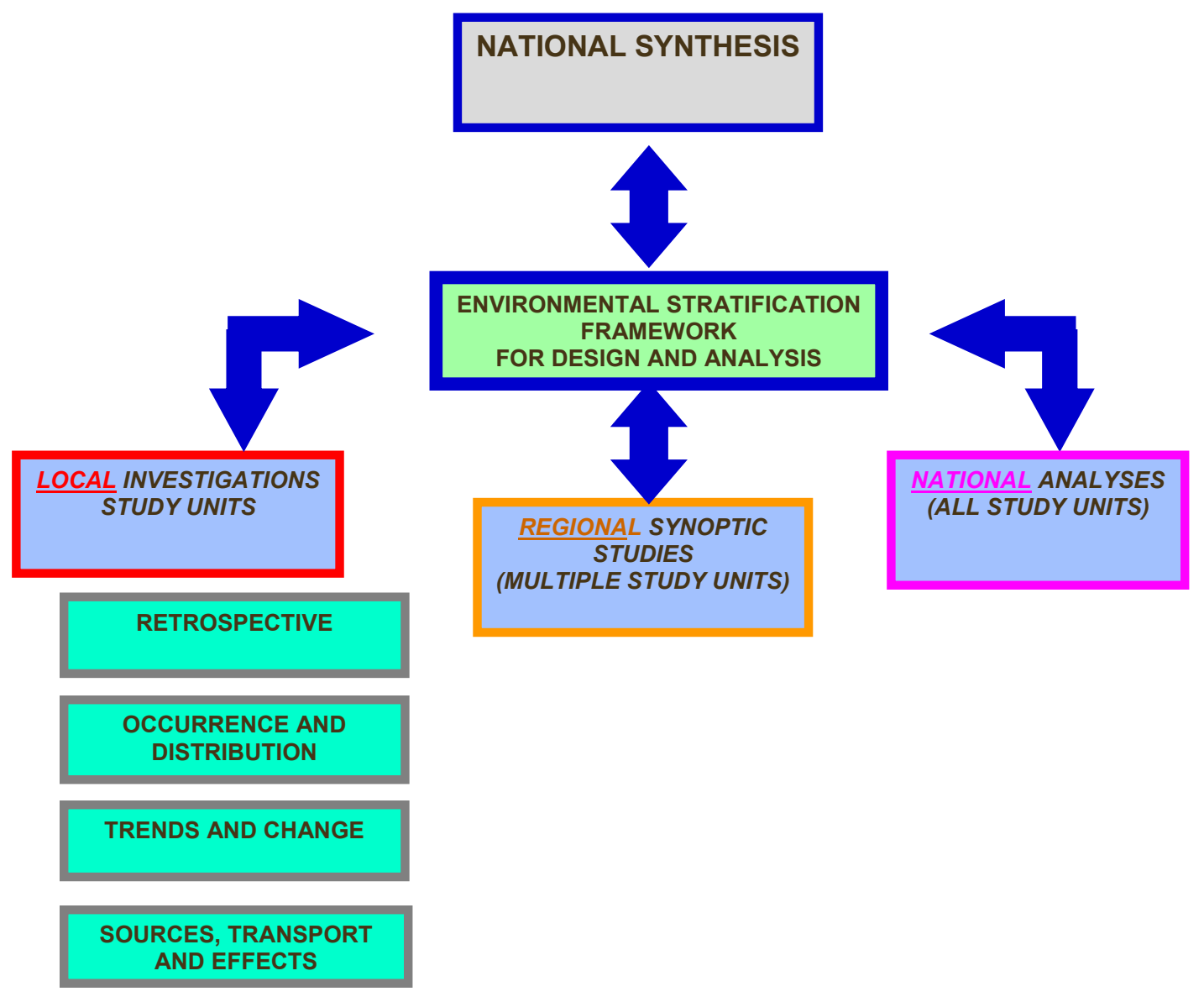

Figure 4. Environmental framework used to synthesize water quality assessment findings. 


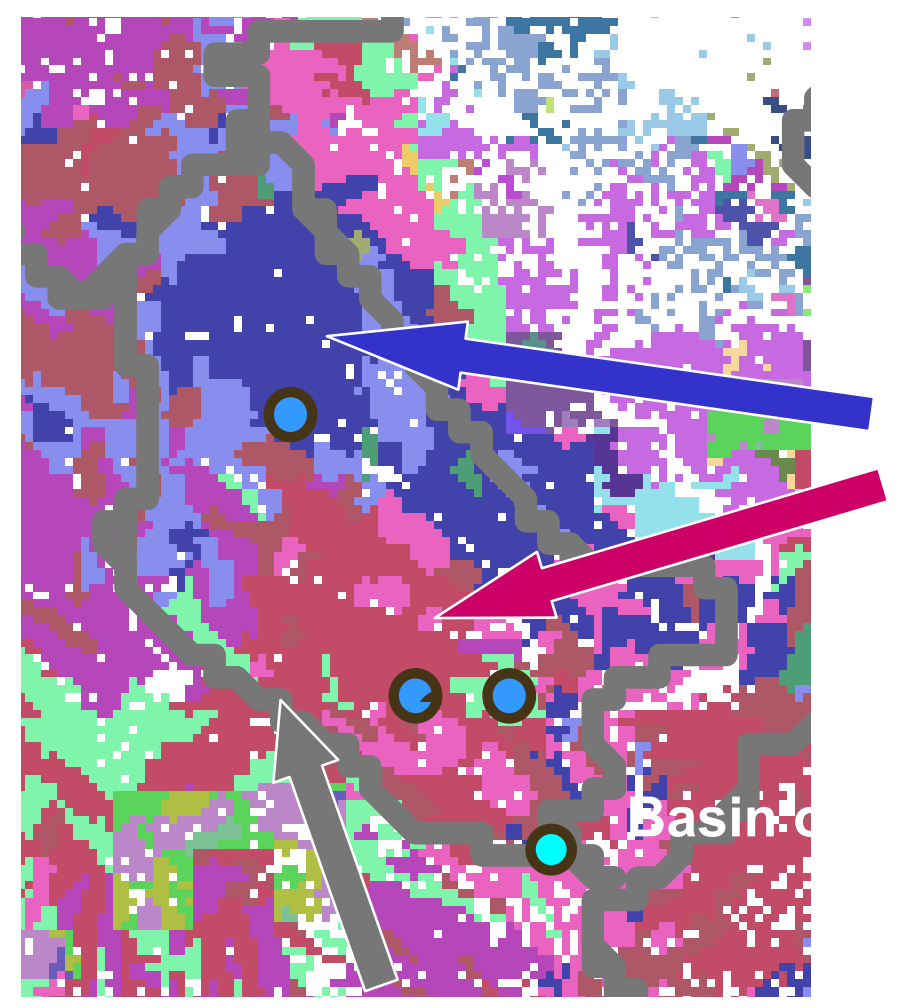

\section{Indicator basins (homogeneous polygons in a Study Unit)}

\section{Integrator basin (heterogeneous Study Unit)}

Figure 5. Study Unit (gray outline) priority mine setting derived by combining deposit groups (source) with hydrologic landscapes (transport). The Study Unit is an integrator basin comprised of smaller homogeneous polygons (red, blue, green). Circles indic ate possible monitoring locations; e.g., surface water hydrology and/or ecology at outlets of tributary basins; ground water within individual colored polygons. 
Table 1. Summary of water-quality assessment activities.

$\left[{ }^{0} \mathrm{C}=\right.$ degree Celcius $; \mathrm{m}=$ meter $]$

\begin{tabular}{|c|c|c|c|c|c|c|c|c|c|c|c|c|c|}
\hline Study Assessment & \multicolumn{9}{|c|}{ First Cycle } & \multicolumn{4}{|c|}{ Second Cycle } \\
\hline Activity $\quad$ Year & - & N & $m$ & 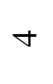 & $n$ & 6 & $r$ & $\infty$ & $a$ & 음 & $=$ & $\simeq$ & 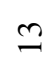 \\
\hline $\begin{array}{c}\text { Analysis, and } \\
\text { Planning }\end{array}$ & & & & & & & & & & & & & \\
\hline $\begin{array}{l}\text { Data collection: } \\
\text { High-Intensity } \\
\text { Monitoring }\end{array}$ & & & & & & & & & & & & & \\
\hline $\begin{array}{c}\text { Data Collection: } \\
\text { Low-Intensity } \\
\text { Monitoring }\end{array}$ & & & & & & & & & & & & & \\
\hline Reports & & & & & & & & & & & & & \\
\hline
\end{tabular}

